\title{
INTERFERENCE OF SOYBEAN AND CORN WITH Chloris distichophylla
}

\author{
Interferência de soja e milho com Chloris distichophylla
}

\author{
Alana Cristina Dorneles Wandscheer ${ }^{1}$, Mauro Antônio Rizzardi²
}

\begin{abstract}
In nature, plants interact with each other and establish positive, negative, and neutral interference relationships. In agricultural ecosystems, crops are usually affected by competition with weeds, and the effects of this process are influenced by the plant population density and proportional abundance and by the species involved. The present study evaluates the competitive interactions of soybean and corn with Chloris distichophylla. Two experiments were conducted in a greenhouse belonging to the University of Passo Fundo during the 2011/12 crop season: one experiment involving corn and C. distichophylla and another involving soybean and $C$. distichophylla. The experimental units were plastic pots, and the treatments were based on a replacement series, with a constant total density of eight plants per pot. The treatments included five combinations of soybean or corn plants with the weed species (8:0,6:2, 4:4, 2:6 and 0:8), corresponding to relative abundances of $100,75,50,25$ and $0 \%$ of the crop species (and the reverse for the weed species). Competitiveness was analyzed using replacement-series experiment diagrams and competitive indices. Total dry matter and plant height were the two variables analyzed. The competitive indices indicated that corn and soybean crops were more competitive than the weed. The plant height was not affected by competition between both the species.
\end{abstract}

Index terms: Weeping fingergrass, competition, crops.

\section{RESUMO}

No ambiente, as plantas interagem mutuamente e estabelecem relações de interferência tanto positivas, negativas quanto neutras. Em ecossistemas agrícolas, as culturas são normalmente afetadas pela competição com plantas daninhas e os efeitos advindos desse processo são influenciados pela população de plantas, densidade e proporção em que se encontram, além das espécies envolvidas. Objetivou-se, neste trabalho, avaliar as interações competitivas de soja e milho com Chloris distichophylla. Para isso, foram feitos dois experimentos em casa-de-vegetação, pertencentes à Universidade de Passo Fundo, na estação de cultivo 2011/12, um entre o milho e a espécie daninha e outro entre a soja e a espécie daninha. As unidades experimentais foram vasos plásticos, cujos tratamentos foram baseados em série de substituição, com densidade final constante de oito plantas por vaso. Os tratamentos foram cinco combinações de plantas de soja ou milho e da espécie daninha $(8: 0,6: 2$, 4:4, 2:6 e 0:8) que corresponderam às proporções de $100,75,50,25$ e $0 \%$ das culturas e o inverso para a planta daninha, respectivamente. A análise da competitividade foi realizada por meio de diagramas aplicados a experimentos substitutivos e índices de competitividade, sendo as variáveis analisadas matéria seca total e estatura de plantas. Os índices competitivos indicaram que as culturas de soja e milho foram mais competitivas do que a planta daninha. A estatura de plantas não foi afetada pela competição entre ambas as espécies.

Termos para indexação: Falso-capim-de-rhodes, competição, culturas agrícolas.

(Received in march 15, 2013 and approved in may 3, 2013)

\section{INTRODUCTION}

Agricultural crops are subject to environmental factors that influence their growth, development and productivity (PITELLI, 1985). Competition is defined as a negative interaction in which individuals compete for resources that are scarce for all organisms coexisting in the same space, causing reduced growth or decreased survival for less-adapted species (FLECK et al., 2009).

The genus Chloris is poorly known and includes numerous species that are distributed in tropical and subtropical regions on multiple continents. Many species of this genus are native to Brazil (KISSMANN, 1997). Among Chloris species, Chloris distichophylla Lag. [synonym: Eustachys distichophylla (Lag.) Nees], commonly known as weeping fingergrass, is found in areas where soybean and fruit crops are grown in southern Brazil (NUNES et al., 2007).

Considering the widespread occurrence of $C$. distichophylla in agricultural regions of southern Brazil and the insufficient information presently available for this species, research on the morphology, behavior, and competitive ability of this plant in the agricultural environment is urgently needed.

1Universidade de Passo Fundo/UPF - 99052-900 - Passo Fundo - RS - Brasil - alanacdw@gmail.com

2Universidade de Passo Fundo/UPF - Passo Fundo - RS - Brasil

Ciênc. agrotec., Lavras, v. 37, n. 4, p. 306 - 312, jul./ago., 2013 
The present study tests the hypothesis that the weed $C$. distichophylla is less competitive than crop species when grown in a mixture in equal proportions. To test this hypothesis, the competitive interactions of soybean and corn with $C$. distichophylla were investigated through replacement-series experiments.

\section{MATERIALS AND METHODS}

The experiments were performed during the 2011/ 12 growing season at the Agricultural Research and Extension Center of the School of Agronomy and Veterinary Medicine, University of Passo Fundo - UPF, Rio Grande do Sul, Brazil.

Seeds of $C$. distichophylla were collected in an agricultural area in the municipality of Redentora, northern Rio Grande do Sul. Soybean [Glycine max (L.) Merr., cultivar NA 5909 RG] and corn [Zea mays L., hybrid DKB $240 \mathrm{YG}]$ seeds were also used.

The experiments were conducted in a greenhouse with an automatic irrigation system programmed for two hours of irrigation daily. The experimental units consisted of plastic pots ( $8 \mathrm{~L}$ in volume, $25 \mathrm{~cm}$ high) filled with soil derived from the experimental area, which is classified as a typical dystrophic Red Latosol. The treatments were arranged in a completely randomized design with four replicates, and the positions of the pots were shifted periodically to obtain homogeneous experimental conditions.

The treatments were based on a replacement series. The population density used for each experimental unit, which was determined in preliminary trials according to the "law of constant final yield" (data not shown), was eight plants per pot. This density is equivalent to 250 plants $\mathrm{m}^{-2}$.

The ratio of soybean or corn to the weed species was $8: 0,6: 2,4: 4,2: 6$, or $0: 8$, corresponding to $100,75,50,25$, or $0 \%$ of the crop species and the reverse for the weed species.

C. distichophylla seeds were placed in a germination chamber at $25^{\circ} \mathrm{C}$ in the dark for approximately three days. After radicle protrusion, the germinated seeds were transplanted to 128-cell styrofoam trays filled with commercial substrate and kept in the trays for 24 days, until emergence. Upon emergence, the seedlings were transplanted permanently to the experimental units (i.e., plastic pots). The soybean and corn seeds were planted seven days before the final establishment of the experimental units so that their emergence coincided with the emergence and transplantation of the $C$. distichophylla seedlings. Thus, each experimental unit contained the crop and weed plants at the same phenological stage.

At the time of crop flowering, 60 days after emergence (DAE) for soybean and 42 DAE for corn, all plants from each treatment were harvested. Plant height, measured as the distance from the base to the end of the last leaf, and total dry matter (root + shoot) were recorded. The harvested plants were washed with running water, placed in paper bags, tagged, and placed in an incubator at $60^{\circ} \mathrm{C}$ for 72 hours. Subsequently, the dried plants were weighed to obtain the total dry matter from each treatment.

The graphical or conventional analysis method for replacement experiments was used to analyze the variables (ROUSH et al., 1989; COUSENS, 1991). This method involves the construction of diagrams based on the relative yield (RY) and relative yield total (RYT) at the relative crop and weed abundances of $0,25,50,75$, and $100 \%$.

The RY for each variable was calculated by dividing the average value of a given mixture by the average value of the monoculture, including the average value of all plants of each species in each experimental unit in the calculation. The RYT was calculated as the sum of the relative yields of the competitors according to their respective proportions.

The formulas used to calculate the RY and RYT were based on those published by Hoffman and Buhler (2002): $\mathrm{RYa}=(\mathrm{p})($ Amix/Amon), $\mathrm{RYb}=(1-\mathrm{p})(\mathrm{Bmix} / \mathrm{Bmon})$, and $\mathrm{RYT}=\mathrm{RYa}+\mathrm{RYb}$, where RYa is the relative yield of species " $a$ " (crop), RYb is the relative yield of species "b" (weed), p is the proportion of "a" in the mixture (\% divided by 100), Amix is the value of the variable to be analyzed (e.g., dry matter) of species "a" in the mixture, Amon is the value of the variable to be analyzed of species "a" in the monoculture, Bmix is the value of the variable to be analyzed of species " $b$ " in the mixture, and Bmon is the value of the variable to be analyzed of species " $b$ " in the monoculture.

The relative competitive ratio $(\mathrm{CR})$, relative crowding coefficient $(\mathrm{K})$, and aggressiveness (A) were calculated based on the mixture containing $50 \%$ of the crop plant and $50 \%$ of the weed species. The CR represents the comparative growth of species "a" (soybean or corn) in relation to that of species " $\mathrm{b}$ " $(C$. distichophylla $), \mathrm{K}$ represents the relative dominance of one species over another, and A represents which species is more competitive (Cousens, 1991). Species "a" is more competitive than species " $\mathrm{b}$ " when CR $>1, \mathrm{Ka}>\mathrm{Kb}$, and A $>0$. Species " $b$ " is more competitive when $\mathrm{CR}<1, \mathrm{Ka}<\mathrm{Kb}$, and $\mathrm{A}<0$. The formulae for these indices are given below according to Hoffman and Buhler (2002): $C R=((1-p) / p)$ $(\mathrm{RYa} / \mathrm{RYb}), \mathrm{Ka}=((1-\mathrm{p}) / \mathrm{p})(\mathrm{RYa} /(1-\mathrm{RYa})), \mathrm{Kb}=((1-\mathrm{p}) / \mathrm{p})$ $(\mathrm{RYb} /(1-\mathrm{RYb}))$, and $\mathrm{A}=(\mathrm{RYa} / 2 \mathrm{r})-(\mathrm{RYb} /(2(1-\mathrm{p})))$.

To statistically analyze the relative yield, the RY differences (RYD) obtained in the treatments with relative abundances of 25,50 , and $75 \%$ of a given species were 
first calculated in relation to the values corresponding to hypothetical lines in the respective proportions $(0.25,0.50$, and 0.75 ). A t-test with an error probability of $5 \%$ was used to identify significant differences in the indices RYD, RYT, $\mathrm{CR}, \mathrm{K}$, and A compared to the hypothetical lines. SAS (Statistical Analysis System version 8.0) statistical software was used to perform these analyses.

The null hypothesis to test the differences in RYD and $A$ was that the means were equal to zero $\left(\mathrm{H}_{0}=0\right)$. For RYT and CR, the null hypothesis was that the means were equal to one $\left(\mathrm{H}_{0}=1\right)$. For $\mathrm{K}$, the null hypothesis was that the means of the difference between $\mathrm{Ka}$ and $\mathrm{Kb}$ were equal to zero $\left[\mathrm{H}_{0}=(\mathrm{Ka}-\mathrm{Kb})=0\right]$.

Total dry matter and plant height were expressed as mean values per plant and subjected to an analysis of variance using an F-ctest. If significant, the treatment means were compared by Dunnett's test, considering the monocultures as the controls. The error probability in all statistical analyses was $5 \%(\mathrm{p} \leq 0.05)$.
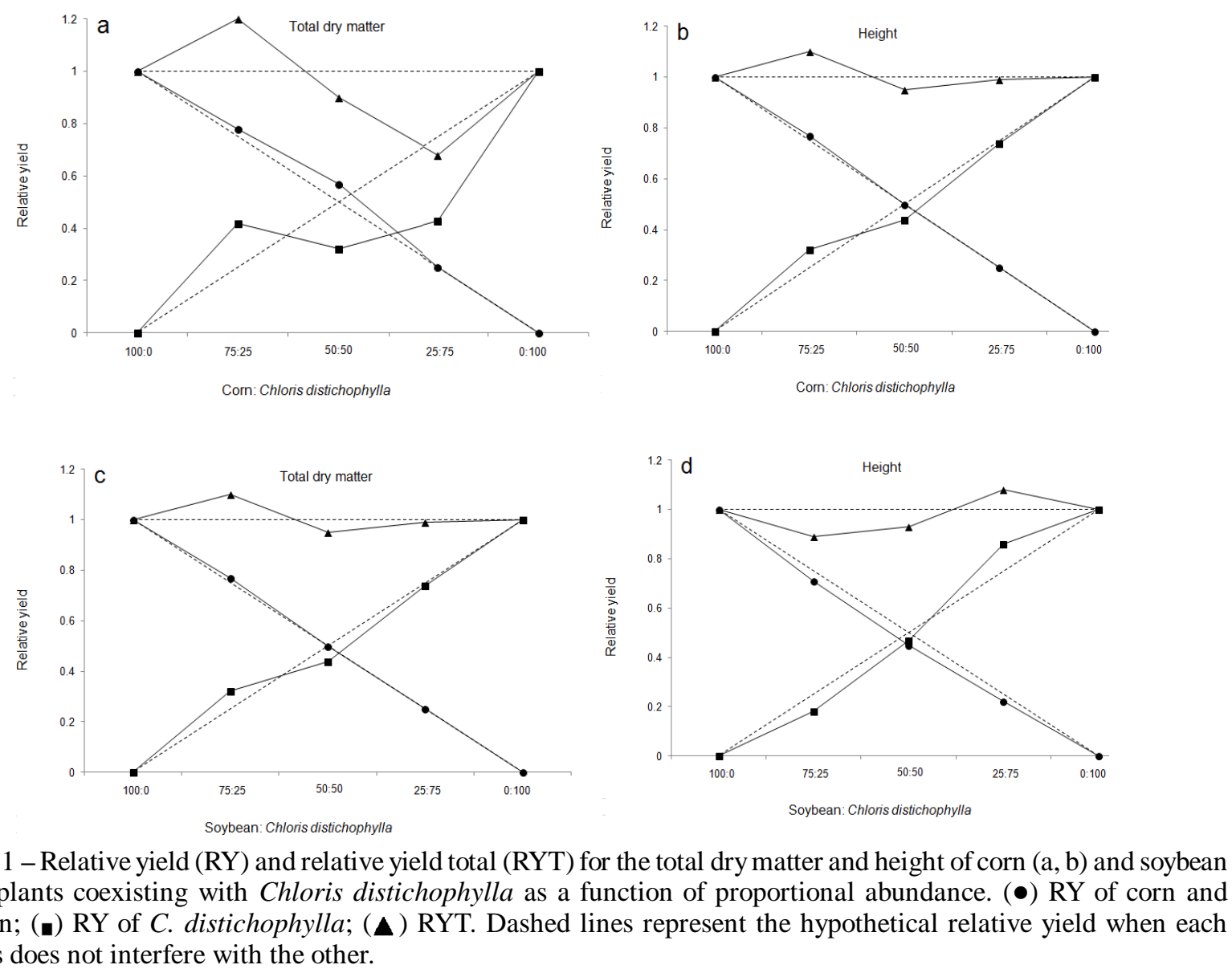

Figure 1 - Relative yield (RY) and relative yield total (RYT) for the total dry matter and height of corn (a, b) and soybean (c, d) plants coexisting with Chloris distichophylla as a function of proportional abundance. (•) RY of corn and

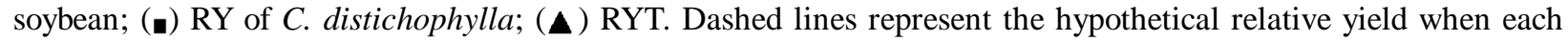
species does not interfere with the other.

Ciênc. agrotec., Lavras, v. 37, n. 4, p. 306 - 312, jul./ago., 2013

The graphical analysis of the RY of total dry matter for corn showed a line near or above one in all combinations with $C$. distichophylla. However, the values obtained did not differ from the hypothetical values for all proportions, suggesting that the corn plants, even under interference with the weed, maintained their productivity as if grown in a monoculture (Figure 1a and table 1). When the observed line does not differ from the expected line, it can be inferred each species' ability to interfere with the other was equivalent and that each species contributed directly to the total dry-matter ratio of the mixture. Thus, the interspecific competition between the crop and the weed was equivalent to the intraspecific competition among crop plants in the absence of weeds (RADOSEVICH et al., 1997).

Figure 1a shows that the observed line for the RY of the total dry matter of $C$. distichophylla deviated from

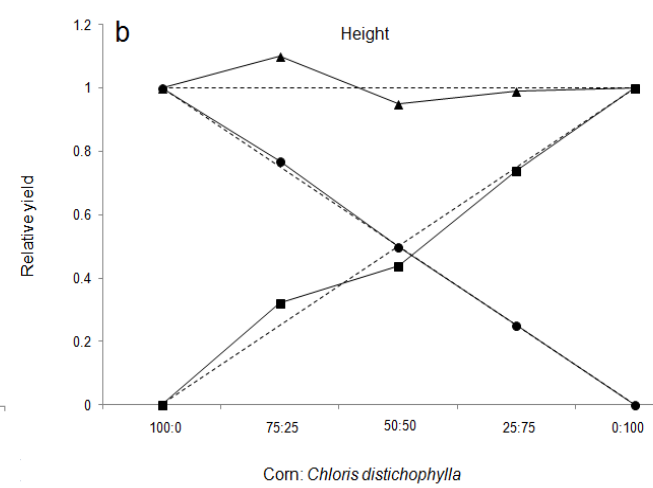


the expected productivity line, as it was higher for the treatment with $75 \%$ corn and lower in the treatments with 50 and $25 \%$ corn. However, these values differed significantly from the hypothetical line only for the treatment with $25 \%$ corn and $75 \%$ C. distichophylla (Table 1). This result suggests that the weed suffered from competitive interference when it was more abundant in the mixture; that is, it suffered more from intraspecific competition than from competition with corn plants. The observed line for the RYT also deviated from the hypothetical line; however, the observed values were different from the expected values only for the treatment with $25 \%$ corn and $75 \%$ C. distichophylla. In this treatment, there was antagonism between the individuals involved, as RYT < 1 (RADOSEVICH et al., 1997). The stresses that occur during the seedling stage can reduce dry matter accumulation that results in grain yield reduction of the population (CERRUDO et al., 2012).

For the RY and RYT of the plant height, the observed values were close to the expected values for all plant ratios and did not differ from the hypothetical line, indicating the absence of competition (Figure 1b). Thus, plant height was not influenced by competition between the species (Table 1).

Although the height of corn and C. distichophylla plants did not significantly differ when the two species were grown in competition, the crop species exhibited noticeably rapid growth compared to the weed species. The $C$. distichophylla plants showed slow initial growth, and due to their smaller size, they likely recruited less soil resources compared to the young corn seedlings. Thus, sufficient resources were available for both species until the total demand was lower than the plants' needs. $C$. distichophylla may be more competitive during regrowth because the plants would then possess features that provide greater competitive ability; however, further research is necessary to confirm this hypothesis.

Although the competition between crop plants is often considered independently of crop-weed competition, the mechanisms through which yields are reduced may be

Table 1 - Relative yield differences (RYD) for total dry matter, plant height, and relative yield total (RYT) among treatments containing corn or soybean plants and Chloris distichophylla plants in the ratios of 75/25, 50/50, and $25 / 75$.

\begin{tabular}{|c|c|c|c|}
\hline \multicolumn{4}{|c|}{ Proportions of plants (Corn/Chloris distichophylla) } \\
\hline & $75 / 25$ & $50 / 50$ & $25 / 75$ \\
\hline \multicolumn{4}{|l|}{$\mathrm{TDM}^{1}$} \\
\hline RYD Corn & $0.03( \pm 0.06)^{\mathrm{ns}}$ & $0.08( \pm 0.04)^{\mathrm{ns}}$ & $0( \pm 0.02)^{\mathrm{ns}}$ \\
\hline RYD Chloris distichophylla & $0.17( \pm 0.05)^{\mathrm{ns}}$ & $-0.18( \pm 0.07)^{\mathrm{ns}}$ & $-0.32( \pm 0.07) *$ \\
\hline RYT & $1.2( \pm 0.11)^{\mathrm{ns}}$ & $0.9( \pm 0.10)^{\mathrm{ns}}$ & $0.68( \pm 0.06) *$ \\
\hline \multicolumn{4}{|l|}{$\mathrm{PH}^{2}$} \\
\hline RYD Corn & $0.02( \pm 0.03)^{\mathrm{ns}}$ & $0.01( \pm 0.03)^{\mathrm{ns}}$ & $0( \pm 0.01)^{\mathrm{ns}}$ \\
\hline RYD Chloris distichophylla & $0.07( \pm 0.05)^{\mathrm{ns}}$ & $-0.05( \pm 0.02)^{n s}$ & $-0.01( \pm 0.12)^{\mathrm{ns}}$ \\
\hline RYT & $1.10( \pm 0.07)^{\mathrm{ns}}$ & $0.95( \pm 0.05)^{\mathrm{ns}}$ & $0.99( \pm 0.12)^{\mathrm{ns}}$ \\
\hline \multicolumn{4}{|c|}{ Proportions of plants (Soybean/Chloris distichophylla) } \\
\hline & $75 / 25$ & $50 / 50$ & $25 / 75$ \\
\hline \multicolumn{4}{|l|}{$\mathrm{TDM}^{1}$} \\
\hline RYD Soybean & $-0.09( \pm 0.04)^{\mathrm{ns}}$ & $0.10( \pm 0.05)^{\mathrm{ns}}$ & $0.17( \pm 0.03) *$ \\
\hline RYD Chloris distichophylla & $-0.21( \pm 0.01) *$ & $-0.35( \pm 0.03) *$ & $-0.33( \pm 0.05)^{*}$ \\
\hline RYT & $0.70( \pm 0.04) *$ & $0.74( \pm 0.04) *$ & $0.84( \pm 0.05)^{\mathrm{ns}}$ \\
\hline \multicolumn{4}{|l|}{$\mathrm{PH}^{2}$} \\
\hline RYD Soybean & $-0.04( \pm 0.03)^{n s}$ & $-0.04( \pm 0.03)^{\mathrm{ns}}$ & $-0.03( \pm 0.02)^{\mathrm{ns}}$ \\
\hline RYD Chloris distichophylla & $-0.07( \pm 0.03)^{\mathrm{ns}}$ & $-0.03( \pm 0.04)^{\mathrm{ns}}$ & $0.11( \pm 0.08)^{\mathrm{ns}}$ \\
\hline RYT & $0.89( \pm 0.06)^{\mathrm{ns}}$ & $0.93( \pm 0.05)^{\mathrm{ns}}$ & $1.08( \pm 0.10)^{\mathrm{ns}}$ \\
\hline
\end{tabular}

${ }^{\text {ns }}$ Not significant and $*$ significant by t-test (pd" 0.05). Values in parentheses represent the standard error of the mean. TDM ${ }^{1}$ : total dry matter (root + shoot); $\mathrm{PH}^{2}$ : plants height. 
common to both. The reductions in the rate of crop growth and development may to be linked to competition for light quantity (PAGE et al., 2010).

The graphical analysis of the competition experiments between soybean and $C$. distichophylla showed that the RY of the total dry matter of the crop deviated from the hypothetical line. This deviation was significant according to the t-test for the treatment containing $25 \%$ soybeans and $75 \%$ C. distichophylla. This result suggests that under competitive conditions, soybean produces more than expected when it is found in a lower proportion in the mixture. Thus, intraspecific competition is more important than interspecific competition (Figure 1c and ttable 1).

Lamego et al. (2005) noted that soybean has high plasticity and shows adaptive responses to the environmental conditions and management to which it is subjected. Thus, under competitive conditions, it can increase its dry-matter production to overcome the competitive ability of the weed species. According to Casper and Jackson (1997), morphological adjustments in response to changes in resource availability facilitate plants' capture of water, light, nutrients, and space, making them more competitive.

The RY of the total dry matter of $C$. distichophylla exhibited significant deviations with values less than 1 in all combinations with soybean, indicating that the weed suffered competitive interference from soybean and produced less than the expected total yield. The RYT of the total dry matter decreased when both species were grown together: RYT < 1 for all combinations (RADOSEVICHet al., 1997) and was significantly different according to the t-test for combinations in which the crop was equally or more abundant compared to the weed (Figure 1c and table 1). Thus, the two species apparently competed for the same environmental resources; however, the soybean plants maintained their productivity under competitive conditions, whereas the weed was negatively affected by the association.

Just as for corn, the RY and RYT of plant height were not affected by the competition between soybean and $C$. distichophylla, although the observed relative-yield lines deviated from the hypothetical lines. The observed values for this variable did not differ from the expected values at any plant ratio, suggesting that competition was absent or that the species' abilities to compete for environmental resources were equivalent (Figure 1d and table 1).

The competitive indices of corn and $C$. distichophylla indicated that the crop was more competitive than the weed. Although the CR index did not show significant differences according to the t-test, $\mathrm{K}$ and A were both significant, and these indices indicate which species is more aggressive and dominates the other species (HOFFMAN; BUHLER, 2002). Here, $\mathrm{Ka}>\mathrm{Kb}$ and A > 0, indicating that corn was more aggressive and dominated over $C$. distichophylla. Plant height was not affected by the competition between the species. Thus, no competitive index for this variable was significantly different according to the t-test (Table 2).

Christoffoleti and Victoria Filho (1996) concluded that corn was a better competitor than redroot pigweed (Amaranthus retroflexus L.). These authors also noted that intraspecific competition was more important for the crop species than interspecific competition with redroot pigweed and that both species competed for the same environmental resources.

In general, replacement experiments demonstrate that crop species have greater competitive ability when they are present in equal proportion to weeds. This pattern is consistent with the findings of the present study. In agricultural environments, weeds are often found in greater density than crops and thus appear to have greater competitive ability than crop species (BIANCHI; FLECK; FEDERIZZI, 2006).

Table 2 - Competitive indices of corn and soybean compared to Chloris distichophylla, expressed by the relative competitive ratio (CR), relative crowding coefficient (K), and aggressiveness (A).

\begin{tabular}{|c|c|c|c|c|}
\hline Variables & $\mathrm{CR}$ & $\mathrm{K}_{\mathrm{c}=\text { corn }}$ & $\mathrm{K}_{\mathrm{C}=\text { Choris distichophylla }}$ & A \\
\hline $\mathrm{TDM}^{1}$ & $2.01( \pm 0.35)^{\mathrm{ns}}$ & $1.40( \pm 0.17) *$ & $0.53( \pm 0.17) *$ & $0.26( \pm 0.06) *$ \\
\hline $\mathrm{PH}^{2}$ & $1.14( \pm 0.06)^{\mathrm{ns}}$ & $1.05( \pm 0.16)^{\mathrm{ns}}$ & $0.81( \pm 0.07)^{\mathrm{ns}}$ & $0.06( \pm 0.03)^{\mathrm{ns}}$ \\
\hline Variables & $\mathrm{CR}$ & $\mathrm{K}_{\mathrm{s}=\text { soybean }}$ & $\mathrm{K}_{\mathrm{C}=\text { Choris distichophylla }}$ & A \\
\hline $\mathrm{TDM}^{1}$ & $4.68( \pm 1.23)^{\mathrm{ns}}$ & $1.66( \pm 0.46) *$ & $0.17( \pm 0.03) *$ & $0.45( \pm 0.08) *$ \\
\hline $\mathrm{PH}^{2}$ & $0.98( \pm 0.10)^{n s}$ & $0.85( \pm 0.10)^{n s}$ & $0.93( \pm 0.13)^{n s}$ & $-0.02( \pm 0.05)^{\mathrm{ns}}$ \\
\hline
\end{tabular}

Ciênc. agrotec., Lavras, v. 37, n. 4, p. 306 - 312, jul./ago., 2013 
The coexistence of corn with $C$. distichophylla increased the total dry-matter production of the weed when it was found in a lower proportion compared to its monoculture. This observation indicates that intraspecific competition was more important for this species. No significant differences in total dry matter were observed between corn grown in a monoculture and corn grown in a mixture, suggesting that neither intra- nor interspecific competition dominated. However, in a study by Marquardt et al. (2012), volunteer corn competition reduced leaf area and biomass of hybrid corn plants, but when volunteer corn grain yield was combined with the hybrid corn grain yield, there was no reduction in total grain yield.

In this study, plant height was not significantly greater or smaller in the mixtures compared to the monocultures and was not influenced by competition between species (Table 3).

The competitive indices ( $\mathrm{CR}, \mathrm{K}$, and A) suggest that for total dry matter, soybean was more competitive than $C$. distichophylla when both species were equally abundant: $\mathrm{Ka}>\mathrm{Kb}$ and $\mathrm{A}>0$ (Hoffman and Buhler, 2002). The indices also indicate that plant height was not affected by competition between soybean and $C$. distichophylla. The observed values of this variable did not differ from the expected values (Table 2).
Bianchi, Fleck and Federizzi (2006) noted that the competitive ability of a species is not defined by a single characteristic but depends on the resource for which it competes and the characteristics of its competitor. Thus, dry-matter production is an essential factor in the competitive superiority of soybean over $C$. distichophylla.

The coexistence of soybean with $C$. distichophylla increased the total per-plant dry matter of the crop when it was found in a smaller proportion in the mixture compared to its monoculture. The weed species exhibited the opposite pattern for the same variable, with lower drymatter production when grown in a mixture compared to a monoculture. This result suggests that soybean prefers to coexist with weed plants rather than with plants of the same species, while the opposite is true for $C$. distichophylla (that is, it prefers to coexist with plants of its own species rather than with soybean plants). Thus, intraspecific competition is more important for the crop, while interspecific competition is more important for the weed. When comparing the plant height of both species grown in monocultures and in mixtures, the observed values did not differ from the expected values, indicating the absence of both intra- and interspecific competition. Both species competed for the same environmental resources; however, the competition between them did not affect their height (Table 3).

Table 3 - Responses of corn and soybean to interference from the competitor Chloris distichophylla at 42 and 60 days after emergence, respectively.

\begin{tabular}{|c|c|c|c|c|c|c|}
\hline Variables & $100 / 0(\mathrm{C})$ & $75 / 25$ & $50 / 50$ & $25 / 75$ & $0 / 100(\mathrm{C})$ & $\mathrm{CV}(\%)$ \\
\hline \multicolumn{7}{|l|}{$\mathrm{TDM}^{1}$} \\
\hline Corn & 1.67 & 1.74 & 1.93 & 1.67 & - & 15.94 \\
\hline Chloris distichophylla & - & $0.017 *$ & 0.006 & 0.005 & 0.010 & 33.64 \\
\hline \multicolumn{7}{|l|}{$\mathrm{PH}^{2}$} \\
\hline Corn & 45.27 & 46.75 & 45.73 & 45.75 & - & 10.16 \\
\hline Chloris distichophylla & - & 4.98 & 3.42 & 3.78 & 3.84 & 26.62 \\
\hline \multicolumn{7}{|c|}{ Proportions of plants (Soybean/Chloris distichophylla) } \\
\hline Variables & $100 / 0(\mathrm{C})$ & $75 / 25$ & $50 / 50$ & $25 / 75$ & $0 / 100(\mathrm{C})$ & $\mathrm{CV}(\%)$ \\
\hline \multicolumn{7}{|l|}{$\mathrm{TDM}^{1}$} \\
\hline Soybean & 9.39 & 8.21 & 11.19 & $15.65^{*}$ & - & 16.68 \\
\hline Chloris distichophylla & - & $0.10 *$ & $0.16^{*}$ & $0.31 *$ & 0.56 & 24.13 \\
\hline \multicolumn{7}{|l|}{$\mathrm{PH}^{2}$} \\
\hline Soybean & 52.56 & 49.93 & 47.89 & 46.43 & - & 11.75 \\
\hline Chloris distichophylla & - & 12.25 & 16.28 & 19.73 & 17.13 & 20.23 \\
\hline
\end{tabular}

* Differs from the average controls $(\mathrm{C})$ by Dunnett's test $(\mathrm{p} \leq 0.05) . \mathrm{CV}=$ coefficient of variation. TDM ${ }^{1}$ : total dry matter (root + shoot); $\mathrm{PH}^{2}$ : plants height. 
The ability to predict the responses of crop plants grown in competition with weeds is essential for control and management programs in agricultural ecosystems. Such predictions can be made based on competition experiments, such as replacement-series experiments (REJMÁNEK; ROBINSON; REJMÁNKOVÁ, 1989). In this context, further studies are needed to verify the responses of crop species under competition with existing weed species, particularly those that threaten productivity. Only with adequate knowledge of the morphology and competitiveness of each species involved is it possible to minimize the interference that may occur in agricultural environments.

\section{CONCLUSIONS}

Soybean and corn crops exhibit competitive superiority compared to the weed species $C$. distichophylla. Plant height is not affected by the competition between species.

\section{REFERENCES}

BIANCHI, M.A.; FLECK, N.G.; FEDERIZZI, L.C. Características de plantas de soja que conferem habilidade competitiva com plantas daninhas. Bragantia, Campinas, v.65, n.4, p.623-632, 2006.

CASPER, B.B.; JACKSON, R.B. Plant competition underground. Annual Review of Ecology and Systematics, Palo Alto, v.28, n.1, p.545-570, 1997.

CERRUDO, D. et al. Mechanisms of yield loss in maize caused by weed competition. Weed Science,

Champaign, v.60, n.2, p. 225-232, 2012.

CHRISTOFFOLETI, P.J.; VICTORIAFILHO, R. Efeitos da densidade e proporção de plantas de milho (Zea mays L.) e caruru (Amaranthus retroflexus L.) em competição. Planta Daninha, Rio de Janeiro, v.14, n.1, p.42-47, 1996.

COUSENS, R. Aspects of the design and interpretation of competition (interference) experiments. Weed Technology, Champaign, v.5, n.3, p.664-673, 1991.

FLECK, N. G. et al. Associação de características de planta em cultivares de aveia com habilidade competitiva. Planta Daninha, Rio de Janeiro, v.27, n.2, p. 211-220, 2009.

HOFFMAN, M.L.; BUHLER, D.D. Utilizing Sorghum as a functional model of crop-weed competition. I. Establishing a competitive hierarchy. Weed Science, Champaign, v.50, n.4, p.466-472, 2002.

KISSMANN, K.G. Plantas infestantes e nocivas. 2. ed. São Paulo: BASF Brasileira S.A., 1997. 825p.

LAMEGO, F.P. et al. Tolerância à interferência de plantas competidoras e habilidade de supressão por cultivares de soja - I. Resposta de variáveis de crescimento. Planta Daninha, Rio de Janeiro, v.23, n.3, p.405-414, 2005.

MARQUARDT, P. T. et al. Competitive effects of volunteer corn on hybrid corn growth and yield. Weed Science, Champaign, v.60, n.4, p.537-541, 2012.

NUNES, A.L. et al. Herbicidas no controle de Chloris distichophylla (Falso-capim-de-rhodes). Revista Brasileira de Herbicidas, Brasília, v.6, n. 1, p.13-21, 2007.

PAGE, E.R. et al. Timing, effect, and recovery from intraspeciûc competition in maize. Agronomy Journal, Madison, v.102, n.3, p.1007-1013, 2010.

PITELLI, R.A. Interferência de plantas daninhas em culturas agrícolas. Informe Agropecuário, Belo Horizonte, v.11, n.129, p.16-25, 1985.

RADOSEVICH, S.R. et al. Ecology of weeds and invasive plants: relationship to agriculture and natural resource management. 3. ed. New Jersey: John Wiley \& Sons, 1997. 454p.

REJMÁNEK, M.; ROBINSON, G.R.; REJMÁNKOVÁ, E. Weed-crop competition: experimental designs and models for data analysis. Weed Science, Champaign, v.37, n.2, p.276-284, 1989.

ROUSH, M.L. et al. A comparison of methods for measuring effects of density and proportion in plant competition experiments. Weed Science, Champaign, v.37, n.2, p.268-275, 1989. 